\title{
REVIEW OF THE CONFERENCE ON LARGE EARTHQUAKES
}

\author{
NAPIER 31 JANUARY TO 3 FEBRUARY 1981
}

\author{
L.M. Megget, School of Architecture, Wellington
}

The Conference on Large Earthquakes was. held in Napier at the time of the 50 th anniversary of the Hawkes Bay Earthquake. The Conference brought together geophysicists, geologists, seismologists, engineers, scientists, architects, sociologists, civil defence staff, the Police, insurance inspectors, builders and people who experienced the earthquakes. The main themes covered included Anticipation of Earthquake Risk, Mitigation of Earthquake Risk (counter measures and Rehabilitation and Reconstruction).

Political Scientist Professor John Roberts gave the opening address, his main message being that all the disciplines represented should work closer together as well as with the general public. This speech set the tone of the Conference, as it soon became obvious that the workers in one discipline knew very little of the new work being done in another discipline.

The Conference guest speaker was Professor Adolf Ciborowski from Warsaw Technical University and his topics were the Pre-disaster planning of human settlements and planning for reconstruction with emphasis on Skopje, Managua, Montenegro and El-Asnam. His main speech concentrated on the planning and reconstruction of Skopje; a mammoth project which included 100 new educational buildings, 14000 prefabricated houses, 25000 new flats (and the repair of the same number of flats), a new city shopping centre and three new bridges over the river varder which was regulated in its course to reduce the possibility of flooding. The slides shown of the reconstruction were impressive although some of the structural forms used to resist earthquake forces seemed dubious to New Zealand engineers. However, the address was very inspiring and Prof. Ciborowski was given a standing ovation on its completion.

The message from the seismologists, geophysicists and geologists was that advances are being made in earthquake prediction (using precursory phenomenon) and the estimation of how often on average, any particular locality is likely to be damaged. However, it will be a long time, if ever, before scientists are able to predict the location and magnitude of a damaging earthquake with a high degree of certainty. The Director of Civil Defence, Major-General Holloway made the point that 'An earthquake prediction leads to a difficult decision on acceptable risk before a warning might be warranted. An earthquake warning is in the end a matter for political judgement based on scientific advice'.

The problems associated with the strengthening and removal of earthquake- risk buildings in Wellington City were explained by Mr K. Mulholland of the Wellington City council. of nearly 800 earthquake-risk commercial buildings in Wellington about $25 \%$ have either been demolished or strengthened to date since 1972 and the council is refusing to issue building permits for major refurbishing unless strengthening is carried out at the same time. Only a few formal notices requiring prompt action under the Municipal Corporations Act have been served where serious defects were apparent in the buildings.

Mr R. Cooney of BRANZ made it very clear that the existing stock of houses in New Zealand will be severely damaged in a major earthquake, in spite of building bylaws introduced since the 1931 Hawkes Bay earthquake. He made special mention of foundation and sub-floor framing construction, masonry veneers, heavy tile roofs, chimneys and water tanks and cylinders - all being critical areas where adequate earthquake resistance is often lacking. Mr Cooney's address made most of the delegates wonder what areas of their own homes were earthquake hazards and some closer inspections may well have been made on their return.

On the topic of response to a major earthquake or disaster, papers were presented by the Australian Counter Disaster College, N.Z. Civil Defence (2), N.Z. Police, the N.Z. Fire Service, and the Ministry of Works and Development and a Building contractor. All the papers emphasised that each field of action needs to be more closely related in the areas of planning and response before and after the disaster.

An extremely interesting paper was presented on the settlement of insurance claims after a major 'quake by Mr J.E. Sherburd, the Past President of the Loss Adjusters of N.Z. A Magnitude 8 earthquake near Wellington would produce an estimated 250,000 claims covering about $\$ 2000 \mathrm{M}$, this being the largest number of claims for any single event ever in the world. The author stated that the settlement of these claims would easily exhaust the Earthquake and War Damage Commissions fund (about $\$ 420 \mathrm{M}$ at present) and involve the government in overseas borrowing and stretch the finances of the Insurance Industry.

The Conference concluded with a successful dinner in the War Memorial Hall built on the land reclaimed by the 31 earthquake. The Conference Proceedings comprising one volume of about 400 pages will be published by the Royal Society of New Zealand in August 1981. Conference delegates will receive a copy free of charge, while other copies will be available at an as yet unknown cost. 